\title{
A PRODUÇÃO DE AUTORIA FEMININA: ALBERTINA BERTHA E A IMPRENSA PERIÓDICA
}

Anna Faedrich Martins

\begin{abstract}
RESUMO: Neste presente trabalho, pretendo mostrar um recorte de uma pesquisa sobre a participação da escritora carioca Albertina Bertha na imprensa periódica da época, bem como a sua atuação na sociedade intelectual do início do século XX, que permanece, até hoje, à sombra dos estudos críticosliterários do Brasil.
\end{abstract}

PALAVRAS-CHAVE: Albertina Bertha. Produção Feminina. Imprensa.

ABSTRACT: This study intends to show an approach of Albertina Bertha's participation in the periodical press, in the beginning of $20^{\text {th }}$, as well as her actuation in the intellectual society, which is in the shadow of the critic and literary Brazilian studies until now.

KEYWORDS: Albertina Bertha. Women's writing. Press.

\section{INTRODUÇÃO}

O trabalho que venho realizando sobre a autora Albertina Bertha é oriundo de um contexto de pesquisa sobre o romance de introspecção no Brasil, que iniciou em 2007, na Universidade Federal do Rio Grande do Sul, com apoio do CNPq. O título do projeto de pesquisa era "Espaços circunscritos e subjetividade: estudos sobre a formação do romance de introspecção no Brasil (1888-1930)", e o recorte temporal permitiu a sua conclusão em 2010, tendo em vista a continuidade nos estudos sobre as narrativas de exploração da subjetividade, através da renovação do projeto ${ }^{1}$ e da extensão no recorte temporal.

O resultado desta pesquisa foi a minha Dissertação de Mestrado, intitulada "O romance de introspecção no Brasil: o lugar de Albertina Bertha”, defendida em janeiro de 2010, na PUCRS. Nesta, pude trabalhar com a formação do romance de introspecção no Brasil; refletir sobre o intercâmbio dialético entre luz e sombra nas Histórias da Literatura; apresentar a autora Albertina Bertha, trazendo à luz dados biográficos e a recepção da sua obra na época; traçar diálogos possíveis com o Simbolismo, o Decadentismo e outros autores da linhagem da

${ }^{2}$ A extensão do projeto deu origem ao que hoje se intitula "Escritas do Eu: perfís e consolidação do romance de introspecção no Brasil (1930-1970)", realizado na PUCRS, cujo período de desenvolvimento será de março/2010 a fevereiro/2013. 
introspecção; e, por fim, analisar os modos de representação psíquica, no âmbito da narratologia, tendo o romance Exaltação como corpus de análise.

Neste presente trabalho, pretendo mostrar um recorte de uma pesquisa sobre a participação de Albertina Bertha na imprensa periódica da época, bem como da sua atuação na sociedade intelectual do início do século XX, que permanece, até hoje, à sombra dos estudos críticos-literários do Brasil.

\section{ALBERTINA BERTHA E A IMPRENSA PERIÓDICA}

Albertina Bertha de Lafayette Stockler nasceu no Rio de Janeiro (RJ) em $07^{2}$ de outubro de 1880 e faleceu, na mesma cidade, em 20 de junho de 1953. Por sua biografia não ter sido documentada, poucas eram as informações que tínhamos a respeito de sua vida pessoal na época da escrita da Dissertação de Mestrado. Hoje, tendo a oportunidade de contatar a sua família, em especial a bisneta Beth Stockler, desfrutamos do acesso a dados pessoais, histórias, lembranças, fotos, entrevistas e documentos importantes sobre a escritora carioca. Esse riquíssimo material será utilizado na elaboração de uma edição crítica, por mim organizada, do primeiro romance publicado por Albertina Bertha, em 1916, Exaltação.

Albertina era filha do Conselheiro Lafayette Rodrigues Pereira ${ }^{3}$ e de D. Francisca de Freitas Coutinho Lafayette, neta dos Barões de Pouso Alegre, pertencia a uma importante família da época, o que não impediu que sua biografia fosse ignorada. Foi educada por uma professora alemã, formada pela Escola Normal de Berlim, que o pai mandara buscar especialmente para a sua educação, preocupado com a qualidade e o refinamento da formação da filha. Albertina aprendeu línguas, estudou Estética e Filosofia, entretanto, sem se distanciar de casa, como era o costume nas famílias abastadas brasileiras. Foi casada com o republicano histórico Alexandre Stockler Pinto de Menezes, com quem teve quatro filhos, Clara, Alexandre, Lafayette e Francisca. De acordo com Beth Stockler, Albertina "tinha marido e

\footnotetext{
${ }^{2}$ Nota-se uma contradição no que diz respeito à data de nascimento da autora. Todos estudiosos que escreveram sobre a autora afirmam que a data é 07 de outubro de 1880 , porém, na nota de falecimento publicada no Jornal do Comércio, consta dia 02 de outubro de 1880. Também a bisneta Beth Stockler afirma ser dia 02.

${ }^{3}$ Sobre a vida do Conselheiro Lafayette e sua importante participação político-histórica no Brasil, existe um livro publicado, Lafayette, um jurista do Brasil, escrito por Maria Auxiliadora de Faria, Lígia Maria Leite Pereira e Paulo Roberto de Gouvêa Medina.
} 
filhos. Não sabia o que era solidão, embora buscasse o silêncio das tardes para conviver com seus personagens, sozinha, longe do ritual da casa". 4

Romancista e ensaísta, a obra de Albertina Bertha é composta por cinco volumes ${ }^{5}$ : Exaltação (romance, 1916), Estudos $1^{a}$ série (ensaio, 1920), Voleta (romance, 1926), E Ela Brincou com a Vida (romance, 1938) e Estudos $2^{a}$ série (ensaio, 1948). Participou, também, da vida jornalística, colaborando ativamente na imprensa carioca, em jornais como $O$ Jornal (para os Diários Associados), Jornal do Comércio, O País, O Malho, A Noite, e em revistas como a Panóplia, publicação literária dedicada às mulheres, e Para Todos. Albertina Bertha foi admitida como Membro da Academia de Letras de Manaus e, conforme Adalzira Bittencourt, ${ }^{6}$ a autora pertenceu a inúmeros grêmios culturais de seu tempo. ${ }^{7}$ Foi, também, introduzida na Sociedade de Homens de Letras, por Olavo Bilac, que admirava seu estilo de fortes influências parnasianas.

$\mathrm{Na}$ imprensa periódica da época, encontramos a participação ativa da autora, que publicou contos literários, trechos de romances, deu entrevistas aos mais variados jornais e revistas brasileiras e estrangeiras, destacou-se pelas palestras e conferências sobre filosofia, que acabara publicando na imprensa, emitiu opinião sobre os assuntos mais variados, tais como o voto feminino, a criação de uma Academia Feminina de Letras e o divórcio. Albertina

${ }^{4}$ STOCKLER, Beth. A volúpia de Voleta. Em memórias de amor. Niterói, RJ: Muiraquitã, 2004.

${ }^{5}$ Nelly Novaes Coelho (2002), em O dicionário crítico de escritoras brasileiras, e Zahidé Muzart (2004), em Escritoras Brasileiras do século XX, apontam que A mulher na guerra seria um romance de Albertina Bertha, cuja data de publicação é desconhecida (s/d). Caso fosse verdadeira essa informação, a obra da autora de Exaltação seria composta por seis volumes, e não cinco conforme mencionamos neste trabalho. Porém, constatamos que "A mulher na guerra" é um ensaio integrante do livro Estudos (1920) e que se refere à conferência que deveria ser realizada em 1918 pela própria autora. Em Estudos, podemos encontrar seis ensaios: "Nietzsche"; "A criança"; "A mulher na guerra"; "Notas de filosofia: Indução. Princípio de causalidade"; "Estética contemporânea"; e "O romance, a sua evolução".

${ }^{6}$ Adalzira Bittencourt (1904-1976), advogada, escritora e feminista, organizou um dicionário, utilizando como critério a ordem alfabética do primeiro nome de mulheres intelectuais e notáveis do Brasil, bem como "senhoras nascidas em outras terras, mas que vivem ou viveram entre nós, assim como brasileiras natas que vivem ou viveram sempre no estrangeiro" (1969, p. 10). Este é um registro importante da participação feminina na vida intelectual, artística e social do Brasil. Adalzira expõe a dificuldade encontrada em realizar esse tipo de trabalho, tanto pela escassez de informações biográficas, como pela dificuldade em conseguir fotografias. A autora afirma que essa não é uma obra de crítica, que este trabalho não mede nem compara valores, sendo assim, "apenas um Dicionário" (p. 12). A intenção é que esses nomes não caiam no esquecimento com o rolar dos tempos e que esse estudo seja uma fonte honesta de consultas. Bittencourt completou apenas três volumes do dicionário, referente às letras $\mathrm{A}$ e $\mathrm{B}$. O terceiro e último volume, publicado em 1972, não foi concluído pela autora. Dentre inúmeros trabalhos, Adalzira Bittencourt publicou: Mulheres e livros (1948), Antologia de letras femininas (1948) e A mulher paulista na história (1954). Sua vasta obra mostra a sua preocupação com a causa da mulher e com a construção da memória feminina brasileira.

${ }^{7}$ BITTENCOURT, Adalzira. Dicionário bio-bibliográfico de mulheres ilustres, notáveis e intelectuais do Brasil. Rio de Janeiro: Pongetti, 1969, p. 114-115. 
escrevia, sem limites, sobre religião, política, filosofia, psicologia e história. Dava conselho às mulheres, demonstrava uma visão crítica da sociedade intelectual predominantemente masculina, reconhecia a necessidade de a mulher mudar a sua postura antes mesmo de exigir seus direitos. A voz de Albertina era muito respeitada, como podemos ver na forma de tratamento à autora publicada nos jornais.

Além dessa produção ativa da escritora na imprensa periódica, onde ela escreve e publica, destacamos a recepção crítica de toda a sua obra, literária e ensaística, que originou uma série de comentários, algumas vezes elogiosos, reconhecendo o talento da escritora, outras vezes severos, acusando a ousadia do seu estilo e o teor de seus romances. Nos jornais, encontramos uma série de publicações, opiniões, polêmicas, notas, recomendações e críticas, sobre a escritora e sua produção intelectual, que confirmam a importância da sua voz na sociedade em que vivia, confirmam a participação ativa que ela tinha no meio literário e cultural da época e, principalmente, para o seu público-leitor. Tal popularidade, infelizmente, não perdurou, pois, hoje, dificilmente se encontra alguém que conheça a escritora.

O primeiro livro de Albertina Bertha, intitulado Exaltação, foi publicado como romance em 1916; entretanto, já havia sido publicado como folhetim no Jornal do Comércio, ${ }^{8}$ mediante o pedido de T. A. Araripe Júnior ${ }^{9}$ e, desde então, sendo alvo da crítica.

Constância Lima Duarte, ${ }^{10}$ ao refletir sobre o cânone e a autoria feminina, observa a dificuldade que a mulher, nos séculos passados e ainda no início do século XX, enfrentava

${ }^{8}$ O Jornal do Comércio, importante jornal econômico brasileiro que teve origem no Diário Mercantil (Francisco Manuel Ferreira \& cia - 1824), foi fundado em 31 de agosto de 1827, pelo francês Pierre Plancher, no Rio de Janeiro. "No influente órgão da imprensa fluminense, a mais antiga folha de circulação diária ininterrupta da América Latina desde a fundação, em suas páginas têm colaborado as mais eminentes personalidades do primeiro e do segundo Império bem como da República até os dias presentes [...]. Durante este período eram colaboradores, entre outros, Justiniano José da Rocha, José Maria da Silva Paranhos (Visconde do Rio Branco, autor, em 1851, das Cartas do Amigo Ausente), Carlos de Laet, Francisco Octaviano, José de Alencar, Homem de Mello, Joaquim Nabuco, Guerra Junqueiro e outros intelectuais. O próprio Pedro II escrevia sob pseudônimo no jornal e influía em seus editoriais, a ponto de um destes ter causado a queda do Ministério. Com seus colaboradores de nível tão alto, o jornal desempenhou o papel de precursor da Academia Brasileira de Letras, cuja fundação somente ocorreria a 20 de julho de 1897, tendo como seu primeiro presidente o escritor Machado de Assis. [...] Entre os colaboradores destacavam-se José Veríssimo, Visconde de Taunay, Alcindo Guanabara, Araripe Junior, Afonso Celso e outros". Disponível em http://www.jornaldocommercio.com.br/, acessado em 13/06/2009, grifo nosso.

9 Tristão de Alencar Araripe Júnior (Fortaleza, 1848 - Rio de Janeiro,1911) foi escritor, crítico literário e advogado. Sua família foi uma das mais importantes do Ceará, no século XIX. Primo de José de Alencar, sua obra literária iniciou-se ligada à ficção, porém tornou-se célebre no campo do ensaio, formando, com Sílvio Romero e José Veríssimo, a trindade crítica da época positivista e naturalista. Araripe Júnior é considerado, no bom e no mau sentido, "padrinho" de Albertina Bertha, uma vez que é ele quem escreve o primeiro registro sobre o romance-estreia da autora, Exaltação. 
para ser considerada escritora e integrar o cânone literário "numa sociedade que se recusava a aceitar a concorrência feminina, em qualquer de seus domínios". ${ }^{11}$ Dessa forma, segundo Duarte, mesmo que a mulher tivesse o incentivo da família, uma educação sólida e a oportunidade de publicar textos, como mostramos ser o caso de Albertina Bertha, a crítica se encarregava de desencorajá-la. ${ }^{12}$

Albertina Bertha cresceu e viveu entre os livros, teve a oportunidade de uma educação refinada e, principalmente, o incentivo à escrita e à leitura por parte do pai:

A biblioteca de papai era imensa - informou-me D. Albertina Berta. Estantes de alto a baixo. Eu cresci entre os livros. Aprendi a ler em francês e foi em francês que escrevi os meus primeiros contos. Papai leu-os e me disse: "Você tem intuição literária". Exultei. "Mas precisa conhecer a nossa língua". E deu-me para ler A Morgadinha do Val-Flor. Aborreceu-me o livro. Papai passou-me, então, a Ulisséia, de Pereira de Castro. Depois, eu quis ler Carlyle ${ }^{13}$. Papai não consentiu. À instâncias reiteradas, indicou-me La Philosophie, de Jourdain, para que aprendesse a linguagem metafísica, a introspecção. Data aí o meu amor à filosofia. ${ }^{14}$

Beth Stockler, bisneta da autora, escreve um livro que dedica a sua bisavó. O título do livro é A volúpia de Voleta, e Voleta é uma personagem de Albertina no romance de mesmo nome. Nas orelhas do livro, Stockler escreve sobre a bisavó e o seu contexto, o que nos permite, também, uma aproximação a esse universo tão distante e apagado da história literária brasileira. Beth Stockler ressalta a vida cultural e intelectual da bisavó:

Conheci uma escritora que poderia ter sido uma das maiores do nosso tempo. Escrevia crônicas, poesias, diários... aproveitava qualquer pedacinho de

${ }^{10}$ Professora da Universidade Federal de Minas Gerais.

${ }^{11}$ DUARTE, Constância Lima. O cânone e a autoria feminina. In: SCHMIDT, Rita Terezinha (Org.). Mulheres e literatura: (trans)formando identidades. Porto Alegre: Editora Palotti, 1997.

${ }^{12}$ Ibid., p. 57.

${ }^{13}$ Thomas Carlyle, escritor inglês, nasceu na Escócia, em 4 de dezembro de 1795 e morreu, em Londres, no dia 4 de fevereiro de 1881. Estudou na Universidade de Edimburgo e, quando leu o livro de Madame de Stael, De l'Allemagne, ficou impressionado e decidiu estudar alemão para ler os filósofos e os poetas germânicos no original. Traduziu em inglês os Années d'apprentissage de Wilhelm Meister, de Goethe, e seu Années de Voyage de Wilhelm Meister. Escreveu uma Vie de Schiller (Vida de Schiller, 1825), além de uma história da literatura alemã, que deixou inacabada. Em 1833-1884, publica o curioso romance Sartor Resartus, que Taine julga ser uma mistura de barroco e de misticismo, de ironias ferozes e de tendências pastorais. Esse livro não despertou muito interesse, enquanto que l'Histoire de la Révolution Française, publicada algum tempo depois, marcou o início de seu imenso prestígio como escritor e pode, ainda hoje, ser considerada como um marco importante da historiografia romântica. LAFFONT-BOMPIANI. Dictionnaire Bibliographique des Auteurs de tous les temps et de tous les pays. Grande-Bretagne: Éditions Robert Laffont, 1952.

${ }^{14}$ BERTHA apud BARBOSA,1954, p. 136. 
papel para anotar aquela ideia brilhante que poderia aflorar a qualquer momento. [...] À sua volta respirava-se inteligência e cultura... Os livros estavam gastos pelo constante manuseio. Livros de temas variados, livros franceses antigos... As páginas marcadas, os parágrafos sublinhados, as margens com anotações e opiniões... livros lidos!!! ${ }^{15}$

Albertina Bertha é uma escritora de grande destaque para a sua época. Através de seus estudos filosóficos e de sua obra literária, despertou considerável interesse e curiosidade nos leitores e críticos. Na terceira edição do livro Exaltação, publicada em 1918, com a qual trabalhamos, encontra-se o prefácio com grande elogio de Araripe Júnior. Esse prefácio é uma carta dele à Albertina Bertha, em resposta aos seus primeiros escritos literários:

Ainda não me restabeleci da surpresa que me causou a Exaltação. Continuo a garantir que o seu livro será o mais vibrante dos romances publicados no último decênio. Salvo Os Sertões, de Euclides da Cunha, não conheço estilo mais percuciente. É esta a verdade que sustentarei na liça, com o valor de cavaleiro medieval. ${ }^{16}$

O primeiro registro sobre Exaltação é uma carta de Araripe Júnior ao Jornal do Comércio, na qual recomenda fortemente a obra de Albertina Bertha para publicação:

Solicitando do Jornal a inserção, nas suas colunas de honra, dos dois capítulos do romance Exaltação, escrito por D. Albertina Bertha, o meu fim é chamar a atenção para um dos talentos femininos que mais me tem impressionado. O romance Exaltação, no seu conjunto, apresenta, quer pela concepção, quer pelo estilo, qualidades extraordinárias. O poder descritivo da autora tem um cunho singular e o colorido da paisagem exibe notas fulgentes que recordam a escola dos coloristas italianos, e, às vezes, o modo do pintor inglês Turner. Os dois trechos, que a autora me entregou, são talvez os que mais lhe agradam. A muitos leitores, porém, parecerão de uma abundância excessiva de adjetivação, devida quiçá à influência dannuziana. Há um lirismo insóbrio! Mas é preciso não perder de vista que essa parte do livro contém justamente o delírio das folias, as comunicações de amantes, vítimas de uma formidável intoxicação pelo amor; além de tudo instruídos, cultos e devorados pela ansiedade de realização de um tipo ético ultra vires. O Jornal, publicando esses fragmentos, não fará senão concorrer para que no horizonte das nossas letras desponte um astro de primeira grandeza. ${ }^{17}$

${ }^{15}$ STOCKLER, 2004, orelhas.

${ }^{16}$ ARARIPE JÚNIOR, In: BERTHA, Albertina. Exaltação. $3^{\mathrm{a}}$ edição. Rio de Janeiro: Jacintho Ribeiro dos Santos Editor, 1918.

${ }^{17}$ ARARIPE JÚNIOR, In: BERTHA, Albertina. Exaltação. $5^{\text {a }}$ edição. Rio de Janeiro: Jacintho Ribeiro dos Santos Editor, 1922. 
Percebemos que no livro Escritoras Brasileiras do século XX - Vol II há um equívoco nas informações a respeito da recepção do romance de Albertina Bertha por parte de Araripe Júnior. Zahidé Muzart (2004), baseada em informações colhidas por Fábio Luz, publicadas em 1927, em Estudos de literatura, às quais não conseguimos obter acesso, afirma que Araripe Júnior não partilhava da mesma opinião dos colegas que elogiavam o romance Exaltação, já publicado no Jornal do Comércio. Essa informação não pode ser verdadeira, pois a carta a qual se refere Muzart está publicada integralmente em algumas das edições do romance, em especial, na terceira e quinta edição, com as quais trabalhamos. Ressaltamos que Araripe Júnior não só elogia o romance Exaltação, como recomenda fortemente a sua publicação. E foi por isso que, desde então, ele ficou conhecido como o "padrinho" de Albertina Bertha.

A estreia do romance mereceu dos críticos em geral grandes elogios. Um crítico desconhecido, que também publicou no Jornal do Comércio, registra a sua opinião a respeito da autora e de Exaltação:

A senhora Albertina Bertha não é um temperamento banal. É uma escritora que revela, exprime, estampa estados de alma tão singulares, situações tão bizarras, sensações tão estranhas, que tudo no seu romance se ressente dessas anormalidades, e tudo, estilo, composição, contextura, tipos, fábulas, é ardente, vivaz, desequilibrado, fogoso, brilhantemente exótico e amorosamente bárbaro e sincero. ${ }^{18}$

Anna Ribeiro de Góes Bittencourt, ${ }^{19}$ entretanto, não partilhava da mesma opinião, publicando, no mesmo ano de estreia do romance, a seguinte resposta ao prefácio de Araripe Júnior:

\footnotetext{
${ }^{18}$ LIVROS novos, In: Jornal do Comércio, 24 de fevereiro de 1916, p. 2.

${ }^{19}$ Anna Ribeiro de Góes Bittencourt nasceu em Sant'Anna do Catu, no município de Itapicuru (BA), em 1843, e faleceu em Salvador (BA), em 1930. Escreveu romances, contos, crônicas e poesias, além de colaborar na imprensa local e participar ativamente da vida cultural e literária baiana. A partir de 1911, passou a escrever regularmente na imprensa católica (A Paladina, O Mensageiro da Fé, A Voz da Liga das Senhoras Católicas), adotando posturas críticas ao feminismo e defendendo os papéis sociais tradicionalmente reservados às mulheres, mas advogando, por outro lado, a igualdade da educação para ambos os sexos. Entre 1913 e 1920 , publicou diversos artigos e poesias na revista $A$ Voz, fundada por Amélia Rodrigues. Colaborou também com jornais locais de grande circulação, como A Bahia, Gazeta do Povo e Diário da Bahia. Essas informações foram retiradas do CEDIC (Centro de Documentação e Informação Cultural sobre a Bahia), disponível em http://www.fcmariani.org.br/arquivo/br_fcm_ab.htm, acessado em 14/06/2009.
} 
Não nego à autora deste livro um belo estilo; e sem dúvida cedendo à sedução desta beleza é que Araripe Júnior teceu-lhe o elogio pomposo que lhe serviu de batismo. Todos sabem a importância de um bom padrinho; muitas vezes é o fator de um brilhante futuro. [...] Pretende igualar Exaltação ao livro do infeliz Euclides da Cunha! Que injustiça! Colocar ao lado de uma obra de peso, útil, primorosamente elaborada, o produto funesto de uma imaginação exaltada! ${ }^{20}$

A aproximação entre Exaltação e Os sertões não parece cabível porque são obras muito diferentes e não podem ser examinadas com os mesmos critérios. Entretanto, a apreciação crítica de Bittencourt é muito severa, ela chega ao extremo de recomendar que as famílias de boa conduta moral não comprem o livro e não permitam que seus filhos o leiam. Percebemos, assim, um discurso preconceituoso e conservador, arraigado na moral e nos princípios da Igreja Católica.

Lima Barreto, Monteiro Lobato, Almachio Diniz, Heitor Muniz, Homero Prates, Humberto de Campos, Orestes Barboza, Joaquim Tomaz, Thomaz Murat são grandes nomes da literatura e da crítica literária que escreveram sobre a Albertina Bertha e sobre a sua produção artística. Também encontramos muitas referências à autora em revistas e jornais, como nas revistas "Del Mundo", de Buenos Aires, e "Fon-Fon", do Rio de Janeiro; e nos jornais "Jornal do Comércio", "O Jornal”, "Gazeta de Notícias", "Correio da Manhã", "A Noite", "O País", "Diário Mercantil” entre outros.

Monteiro Lobato, no artigo "Em pleno sonho", de 1926, publicado Na antevéspera ${ }^{21}$, fala que "Albertina Berta documenta a capacidade feminina para voos elegantes sobre cumeadas alpestres onde esvoaçam os d'Annunzios" (LOBATO, 2008, p. 194). Humberto de Campos diz, em entrevista à revista Para Todos, que a Albertina Bertha é uma autora que merece ser lida. Assim como a recepção de sua obra Estudos foi de uma repercussão estupenda. No Correio da Manhã, “A escritora patrícia Albertina Bertha surge, agora, com um novo livro: Estudos. [...] Incontestavelmente, é um excelente livro, revelador duma brilhante inteligência e duma cultura muito rara na gente feminina". No Jornal do Comércio, "A sra. Albertina Bertha com os seus 'Estudos', livro de ensaios filosóficos, vem de renovar entre nós a 'gaia ciência"”. Ainda no Jornal do Comércio, em "Livros Novos",

\footnotetext{
${ }^{20}$ BITTENCOURT, In: A Voz da Liga Católica das Senhoras Baianas, setembro de 1916, n. 6, p. 91-3.

${ }^{21}$ Trata-se de uma reuniáo de artigos publicados n'O Jornal, de Assis Chateaubriand, entre 1925 e 1926, e n'A Manhã, de Mário Rodrigues, ambos do Rio de Janeiro.
} 
A Sra. Albertina Bertha teve no romance Exaltação uma estreia sensacional nas letras brasileiras. O seu livro é, de fato, pela estética que revela, pela impetuosa beleza de estilo, pela frase quente e espumante, dos mais fortes e característicos que a moderna geração brasileira tem produzido. Assim, a Sra. Albertina Bertha conquistou, de um só impulso, todo o sucesso que o nosso acanhado mundo literário pode proporcionar. E o sucesso foi merecido. Há uma grande alma de artista, de poeta e de filósofa naquele romance, que é um hino à natureza, à beleza e ao amor.

Nada mais natural do que receber um livro de filosofia da mesma autora de Exaltação. No romance, a Sra. Albertina Bertha demonstrou cultura que indicava conhecimentos filosóficos e científicos. Os Estudos, agora publicados, confirmam a artista.

Na revista Fon-Fon,

A inteligente senhora Albertina Bertha, pensadora e filósofa, um dos reveladores de Nietzsche no nosso meio, publicou mais um livro que é mais uma prova da sua vasta cultura e do seu amor às letras pátrias, para as quais tem constantemente e brilhantemente concorrido.

Neste novo volume, otimamente escrito, a admirável escritora patrícia enfeixa diversos estudos de real valor, cada um dos quais atesta o grande poder de sua inteligência, talvez a maior inteligência feminina do Brasil.

E, assim, somos capazes de citar aqui inumeráveis artigos elogiosos sobre os livros de Albertina Bertha, publicados na imprensa periódica da época. Entretanto, gostaríamos de dar um enfoque especial, nesta apresentação, para a participação ativa da escritora nos periódicos.

Sua participação se deu de diversas formas. É impressionante o número de entrevistas que Albertina Bertha cedera aos jornais e revistas. Ela opinava sobre os mais variados assuntos, e podemos perceber que sua opinião era muito importante para esses veículos de comunicação e, também, sempre muito respeitada. No Correio da Manhã, de sábado, dia 16 de janeiro de 1926, Albertina fala sobre o papel da mulher na política brasileira e dá a sua opinião sobre a criação de uma Academia Feminina de Letras.

Primeiramente, percebemos o respeito com que os jornais da época se referiam à autora e o reconhecimento do valor de sua obra. A Revista Fon Fon, do dia 10 de julho de 1920, publica sobre o livro Estudos uma matéria elogiosa, que termina dizendo: "A senhora Albertina Bertha, que é uma alma varonil e um espírito forte, mais adiantado que o seu meio, nele mostra quão profundamente o seu coração é um grande coração de mulher". Em "Livros Novos", do Jornal do Comércio, de 09 de julho de 1920, outro elogio: “Assim os Estudos 
colocam a Sra. Albertina Bertha no primeiro plano dos nossos críticos, publicistas e ensaístas como Exaltação a colocara na primeira linha dos romancistas”. Homero Prates, n’O País, de 09 de setembro de 1920, afirma, sobre Albertina Betha e seus Estudos: "Das atuais escritoras nacionais, nenhuma merece mais o estudo acurado da crítica do que a Sra. Albertina Bertha [...] é um livro grave e másculo, substancioso e forte, absolutamente emancipado de todos preconceitos [...]". Em "Livros Novos", do JC, no dia 05 de dezembro de 1925, encontramos mais uma matéria em prol da escritora e de seu trabalho, como em tantos outros recortes de jornais da época: “Albertina Bertha é, portanto, hoje, um dos nossos grandes nomes literários, escritora de formidável poder de expressão, romancista que sabe traduzir as ansiedades da alma humana, o crítico erudito e vibrante".

Sobre a Academia Feminina, Albertina demonstra simpatia com a ideia: "Eu sou partidária entusiasta da ideia. Tudo o que eleva e exalta a mulher tem as minhas simpatias e o meu apoio". E fala sobre a primeira academia feminina no mundo, mostrando a riqueza de seus conhecimentos culturais: "Coube a Portugal a primazia. Foi no século XVI, no reinado creio que de D. Manoel. Sob a direção de uma infanta congregaram-se diversas mulheres de letras que prestaram à literatura portuguesa serviços excelentes".

Desta mesma entrevista, temos uma declaração extremamente pessoal da autora, que revela um pouco do seu perfil:

Vivo entre os livros. O meu prazer é o estudo. Gosto imenso de escrever... Não frequento festas. Vou raramente a espetáculos, a passeios... Saio pouco de casa. A muitas amigas tenho dito: vocês sentem prazer e se divertem nas festas, nos banhos, nas danças, nos teatros... E vivem felizes! O meu prazer, o meu divertimento... é o livro, é o estudo... E sou feliz assim!

Em outra entrevista, para o mesmo jornal, no dia 23 de setembro de 1926, Albertina fala a respeito do divórcio e demonstra uma visão crítica sobre o comportamento da mulher em geral. A sua opinião não é contra o divórcio, mas a favor de uma mudança de comportamento que deve ser anterior à idealização de que o divórcio resolve muitos problemas:

O divórcio não se revela uma reivindicação de justiça, um desagravo, um direito, apresenta-se, ao contrário, como uma instituição artificial, hostil à vida das nações e ao destino das sociedades.

Compreendo que seja quase uma impossibilidade a fixidez eterna do casamento na mobilidade vertiginosa do universo, mas também não admito 
que o divórcio represente uma finalidade, a solução ideal para o reestabelecimento da harmonia violada.

É uma arma de gumes duplos que se adita as mãos recursos do homem contra nós, é mais um meio que se lhe proporciona para escapar com dignidade aos encargos e às responsabilidades de chefe da família.

Outra entrevista que a escritora cede ao jornal é sobre o voto feminino. Percebemos que Albertina Bertha participa ativamente de assuntos dos mais variados e de decisões importantes em voga na época. Para cada situação, ela tem uma opinião própria, uma reflexão a acrescentar e a estimular a sociedade a pensar mais profundamente nos assuntos.

Continuando a nossa 'enquete' sobre a questão do voto feminino fomos ouvir a notável e vigorosa brilhante prosadora d. Albertina Bertha, incontestavelmente uma das figuras mais representativas da literatura nacional e autora da 'Exaltação', que não é contrária ao voto feminino muito pelo contrário, considera-o apenas extemporâneo atualmente.

Enquanto a mulher tiver como preocupação exclusiva os chás dançantes e o teor dos vestidos e dos chapéus, enquanto se limitar às mil futilidades que uma vida ociosa provoca, ela permanecerá eternamente vítima de si mesma, jungida à sua inferioridade, incapaz de se erguer, de se reabilitar mesmo que todas as garantias libertárias a rodeiem [...] Do contrário será uma lei morta $^{22}$.

Além desses assuntos, ela escreveu sobre o trabalho feminino, a vocação, sobre a participação feminina na guerra, sobre psicologia, sobre crianças, sobre religião, sobre o Imperador Pedro II, sobre a morte do Padre Natuzzi, sobre filosofia, literatura entre outros..

Albertina Bertha aparece como colaboradora da revista Panóplia, onde ela também publica um conto literário, “O desejo da nuvem”, um ano depois de publicar o romance Exaltação. Neste conto, o teor erótico está presente, assim como o adultério enquanto temática: "Pedro Sandoval, ao findar a leitura dessa carta, exclamava a soluçar, entre dentes: Maldição! Maldição! Totalmente impotente contra a mulher de seu melhor amigo" (BERTHA, O Desejo da Nuvem, Revista Panóplia, out/1917, p. 212).

${ }^{22}$ Este recorte de jornal foi cedido pela família da Albertina Bertha e não consta data nem local de publicação. Ainda estamos investigando esta fonte, tendo em vista que a autora publicava em diversos jornais da época. 
Nos anos 1927 e 1928, o jornal "O Malho" realizou um concurso para promover o "Príncipe dos prosadores brasileiros". Albertina Bertha aparece lá, entre os votantes, mostrando, mais uma vez, a sua intensa participação na elite intelectual da época. O príncipe dos prosadores seria o ganhador da eleição, feita por votos: “A escolha far-se-á unicamente entre os prosadores, isto é, entre aqueles brasileiros vivos que melhor puderam, na novela, na crônica, no ensaio, na crítica, no romance, no teatro, na história tratar o nosso idioma. E será por eleição". Entre os candidatos estavam Coelho Neto, Gilberto Amado, Monteiro Lobato, Humberto de Campos, Viriato Correia, José do Patrocínio, Afrânio Peixoto, Graça Aranha, Agripino Grieco, etc. O voto de Albertina foi para Gilberto Amado (que obteve 85 votos), mas o vencedor, o príncipe dos prosadores brasileiros eleito, foi o Coelho Neto, com 92 votos.

Albertina Bertha destacou-se, também, pelas conferências que ela proferia. A maioria delas foi ao Salão do Jornal do Comércio. Lá, ela falou sobre Nietzsche, sobre um estudo psicológico da criança, sobre a mulher na guerra, sobre estética, romance, estudos filosóficos, etc. Realizou conferência para as moças da Associação Cristã Feminina, onde falou sobre "Como tornamo-nos interessantes". Entre os conselhos da autora, estão:

O homem detesta ouvir de lábios femininos recriminações - palavras severas, radicais, que advertem e amesquinham. Como chefe e autoridade não se resignará facilmente a essa humilhação que o desprestigia. Involuntariamente e, a pesar seu, o olhar, a fisionomia se embruscam e as palavras lhe sairão atropeladas, nervosas. Nesse momento, aconselho a todas vós não reagir, não invectivá-lo de adjetivos desagradáveis para não parecerdes desinteressantes. A mulher tomada de cólera, desnuda atavios que a colorem de magníficas intensidades se descentraliza, torna-se grotesca e banal. [...] A meiguice, o devotamento e a inteligência conferem à mulher uma languidez ardente e apaixonada que impressiona, subjuga e faz com que o homem anseie identificar-se com essa criatura iluminada e infinitamente doce. (BERTHA, 1948, p. 245-246).

Algumas dessas conferências foram publicadas em dois volumes de Estudos $\left(1^{\mathrm{a}}\right.$ e $2^{\mathrm{a}}$ série).

Em 21 de junho de 1953, o "Jornal do Comércio" publicava a nota de falecimento da "ilustre escritora Albertina Bertha", que ocorreu no dia anterior, aos 73 anos:

Os meios literários do país receberam, com grande consternação, a notícia de falecimento da brilhante escritora D. Albertina Bertha, personalidade vigorosa que se impusera, logo ao fazer suas estreias nas letras, à admiração dos nossos meios culturais. 
Individualidade forte, antecipada no tempo pela aprimoração de suas ideias, que surgiam ao comum, D. Albertina Bertha cedo chamou a si as atenções de quantos se interessam pelo nosso desenvolvimento cultural, granjeando os aplausos que jamais desmereceu, em toda a sua longa existência e que bem traduziam a admiração de todos pela sua obra até certo ponto ousada, mas digna dos encômios que lhe foram endereçados.

O aparecimento de D. Albertina Bertha na vida literária do país constituiu um fato de grande repercussão, pois sua obra de estreia, o romance 'Exaltação' trazia a marca ainda não conhecida de um espírito cintilante e, ainda que não fosse impecável na forma, constituía uma mensagem falada a não se perder na inocuidade dos elogios fáceis e no efêmero de fingidas glórias: era algo de novo em nossas letras, novas ideias, nova concepção, tudo revestido num estilo vivo, palpitante, estuante de vida. Ao mesmo tempo, era uma obra personalíssima, original, liberta de qualquer filiação a escolas literárias, valendo, a propósito, lembrar o seu conceito de arte: 'É uma impossibilidade a luta de Escola: a arte não é um elemento abstrato, idêntico a si mesmo, porém, um movimento dinâmico, que muda, sem hierarquias e privilégios; o seu senso de universalidade se estende a todas as manifestações do pensamento e da imaginação; o escritor deve, portanto, apresentar-se livremente, ousadamente, com o seu estilo, a sua maneira de ser, a sua intuição maravilhosa. E a Escola que trouxer as características permanentes da vida, a sua realidade e a sua magnificência não fenecerá, será a escola diretriz, a que terá por missão completar, com a violência do presente, a luminosidade do passado".

E ela mesma confessava que, ao se fazer escritora, "obedecia a uma tendência forte, irresistível, doentia".

Araripe Júnior, assinalando o aparecimento de Albertina Bertha no cenário de nossas letras, afirmou ser 'Exaltação' - 'o mais vibrante dos romances publicados no último decênio'.

E, deve notar-se, a sequência das publicações dessa admirável escritora, foi uma constante reafirmação de seu talento criador para caracterizar-se, mais tarde, como uma obra de unidade, um todo valioso.

Ao desaparecer, Albertina Bertha deixa o traço luminoso de sua passagem, sublinhando a legenda vitoriosa de seu nome. [...].

Depois de todo o nosso trabalho investigativo sobre a biografia, a recepção crítica da obra e a participação da escritora Albertina Bertha na imprensa periódica e na vida cultural do início do século XX, o imenso número de artigos, publicações, referências à autora, os documentos que comprovam que sua produção literária e ensaística era lida, publicada por grandes editores, recomendada por grandes figuras do cenário literário, reconhecida e respeitada na época em que vivia, assim como a repercussão abaladora de seus romances e estudos filosóficos, a polêmica gerada em torno do teor erótico e ousado de seus textos, a sua contribuição para o avanço do papel feminino na sociedade brasileira, depois de toda a nossa 
trajetória em busca de dados sobre uma escritora que foi apagada da historiografia literária brasileira, fica difícil acreditar que, mediante a abundância de fatos e dados, tal sombra possa ter ocorrido.

Quando comecei a pesquisar sobre a Albertina, não imaginava que a atuação dessa mulher no campo das letras fosse tão efetiva e produtiva. Dessa forma, o silêncio existente em torno da ensaísta e romancista carioca representa não apenas uma injustiça, mas uma lacuna na História da Literatura Brasileira.

\section{REFERÊNCIAS:}

BARBOSA, Francisco de Assis. Lafayette Rodrigues Pereira visto por D. Albertina Berta In: Retratos de Família. Rio de Janeiro: José Olympio, 1954, p. 131-140.

BARRETO, Lima. Impressões de Leitura. $2^{\mathrm{a}}$ edição. São Paulo: Brasiliense, 1961.

BERTHA, Albertina. Exaltação. $3^{\text {a }}$ edição. Rio de Janeiro: Jacintho Ribeiro dos Santos Editor, 1918.

BERTHA, Albertina. E ela brincou com a vida. Rio de Janeiro: Borsoi, 1938.

BERTHA, Albertina. Voleta. Organização, atualização e notas Geysa Silva. Rio de Janeiro; Brasília: INL - Instituto Nacional do Livro, 1987.

BERTHA, Albertina. Estudos. $1^{\text {a }}$ série. Rio de Janeiro: Jacintho Ribeiro dos Santos Editor, 1920.

BERTHA, Albertina. Estudos. $2^{\mathrm{a}}$ série. Rio de Janeiro: A. Coelho Branco $\mathrm{F}^{\mathrm{o}}$ Editor, 1948.

BITTENCOURT, Adalzira. Dicionário bio-bibliográfico de mulheres ilustres, notáveis e intelectuais do Brasil. Rio de Janeiro: Pongetti, 1969.

COELHO, Nelly Novaes. Dicionário crítico de escritoras brasileiras: (1711-2001). São Paulo: Escrituras, 2002.

COELHO, Nelly Novaes. O desafio ao Cânone: consciência história versus discurso em crise. In: CUNHA, Helena Parente (Org.). Desafiando o cânone: aspectos da literatura de autoria feminina na prosa e na poesia (anos 70/80). Rio de Janeiro: Tempo Brasileiro, 1999, p. 9-14.

DINIZ, Almachio. Meus odios e meus affectos. São Paulo: Monteiro Lobato \& Cia, 1922. 
DUARTE, Constância Lima. O canône e a autoria feminina. In: SCHMIDT, Rita Terezinha (Org.). Mulheres e literatura: (trans)formando identidades. Porto Alegre: Editora Palotti, 1997.

LAJOLO, Marisa. "Literatura e história da literatura: senhoras muito intrigantes". In: MALLARD, Letícia et al. História da literatura - ensaios. Campinas: Ed da Unicamp, 1994, p. 19-36.

LOBATO, Monteiro. Na antevéspera. São Paulo: Globo, 2008.

MUZART, Zahidé Lupinacci. Escritoras Brasileiras do Século XIX. Antologia Volume II. Rio Grande de Sul: Edunisc, 2004.

SANTOS, André Luiz dos. Caminhos de alguns ficcionistas brasileiros após as Impressões de Leitura de Lima Barreto. Tese (Doutorado em Letras - Literatura Brasileira) Universidade Federal do Rio de Janeiro, Faculdade de Letras, 2007.

SILVA, Auristela Oliveira Melo da. A mulher no limiar do século XX em "Exaltação" de Albertina Bertha. Dissertação de Mestrado em Letras - Universidade Federal de Pernambuco, 1999.

STOCKLER, Beth. A volúpia de Voleta: em memórias de amor. Niterói, RJ: Muiraquitã, 2004.

TACQUES, Alzira Freitas. Perfis de musas, poetas e prosadores brasileiros. V.I. Porto Alegre: Thurmann, 1956.

RECEBIDO EM: 07 de maio de 2012

APROVADO EM: 04 de junho de 2012 